\title{
Africans in America:
}

\section{Ghanaians in Dallas, an Illustration and Study of the Impact of Roots, Ritual, and Religion}

\author{
Erin C. Kincaid
}

\begin{abstract}
The Ghanaian community of Dallas-Fort Worth, Texas, demonstrates the human expressions of meaning in historical connections, dignity and honor, and religious/spiritual and ethical living. My ethnographic research in this community explored their worldview, patterns of behavior, and rituals. Unknown genealogies, the lack of roots, lack of spiritual and moral compass, and absence of a healthy family system/structure all have a devastating and adverse effect on a community. But these are not present in the Ghanaian community of North Texas. This is an example of a community that has overcome adverse experiences by creating social structures and living out Christian beliefs and practices that contrast with these negative elements. I provide here a glimpse into a group that has faced hardships such as life transition, migration, oppression, and economic difficulties . . . and overcome.
\end{abstract}

\section{Introduction}

"Do not follow the path. Go where there is no path to begin a trail." Ghanaian Proverb

When I began my fieldwork with the Ghanaian community of Dallas-Fort Worth (DFW), Texas, it was not with a singular theory or question in mind. I did not go in seeking one truth. I entered my fieldwork believing only one thing: There was/is an uncanny, uncharted, and mysteriously intriguing energy, which encouraged my research choice, to this Ghanaian community. It was in starting without any path ahead of me that I discovered the most hopeful of trails, one that provided a sense that many of the answers about life, love, honor, and unity could be found in a people who have encountered difficulty with grace.

What began as a desire to investigate their proverbs, both historical and present, to explore the notion that these proverbial statements may still hold truths which have value in their present daily life and community, ended in a much broader view of what life with connection and meaning looks like. What I did not expect was the effect and impact this fieldwork would have upon my own worldview and understanding of life, faith, and community. As each step forward provided more backdrop, a series of patterns revealed themselves. It was within emerging examples, truths, and patterns that the real story of modern Ghana in America came alive.

\section{History}

The history of the Ghanaian peoples, both those in Ghana and those living abroad, provided information salient to my research. From the sixteenth century forward, the people of Ghana have maintained a unique duality between themselves and their rulers, oppressors, and colonizing entities. This ability to live within two groups, to reside amid and within those that conquered their lands and people while retaining access and rights over their own leadership, is unique for most post-colonial settings. Theirs is a unique type of social duality. Perhaps this duality is due to the fact that the Europeans who first came to Ghana were in competition with one another to favor and protect the various tribal groups and leaders (Konadu \& Campbell 2016 , i). Perhaps it was the richness of the ruling tribes, namely the Ashanti and Ewe, which provided Ghanaians with an air of royalty not extinguished through conquest and colonization. Conceivably, it could be due to the Christian principles that became prominently rooted in Ghana hundreds of years ago through missionary efforts, and which gave way to common beliefs and a confident lifestyle in the present peoples.

By exploring social issues (historical connectivity, proverbial nuances, the diaspora, community celebrations, legacy building, tribal royalty living in North Texas, parenting, faith-based practices and beliefs, the data on matters such as crime, divorce, and 
single parenting, cultural education, and shame and honor as tools for community cohesiveness), the differences between their community here in the United States and those in the homeland, along with the changes or losses they have experienced when assimilating into the American landscape, I was able to view a micro-community which day by day presented a positive response to the macrolevel of American society. By taking an in-depth look into the history and culture of these Ghanaians, we bring forth the character of this community and discover why and how they retain and perpetuate high values, ethical standards, and morals within an increasing population of migrant expatriates. In addition, exploration around the concept of being Africans in America, as opposed to African Americans, produced important statements on the uniquely Ghanaian set of behaviors, attitudes, life choices, community belonging as well as social, educational and cultural expectations.

Ghanaian history is about strong leadership, abundant gold, fertile soil, productive trade markets, sophisticated social and cultural orders, an uncanny ability to live within two worlds-retaining peace and leadership with other ruling nations, and an aptitude to overcome adverse historical difficulties. These ingrained historical understandings, beliefs, and behavior systems have trickled down over the years to influence the lives of present-day Ghanaians in DFW.

For many cultures, history this far back may be known but not recognized in present-day activities or everyday behaviors. But with Ghanaians it is different. They are aware, proud, and well-integrated into their backstories and history, their past being unmistakably present in contemporary worldview and behaviors, as is evident in their activities, speech, and celebrations. What is prevalent in this group is how historical roots appear at every turn within daily activity and community character, which includes: borderless languages, middlemen leadership, a proverbial mindset, fluid travel and movement between homeland and foreign land, extensive knowledge, and beliefs about past historicities (Conrad 2005, 120). This knowledge of self, this connection to the deep, plays a significant role in their ability to succeed and overcome difficulties along the way. In particular, the form and example of connected genealogy is in marked contrast to an opposite experience that I term, blank genealogy, and the harm it has caused the African American people.

\section{Ethnography (Abridged)}

"When you are sitting in your own house, you don't learn anything. You must get out of your house to learn.” Ghanaian Proverb

\section{Finally, the Truth}

As she approaches, I stand and shift my notebook to the left hand so that I may offer her my right hand in a handshake. She waves my hand away. Shaking her head, she declares, "No, no, we don't shake hands. We hug." Her outstretched arms move almost over my head as she wraps them around me and pulls me into her chest. She squeezes me tight, lets out a little grunt of satisfaction, and pats me on the back with one hand. When she has embraced me long enough, or maybe I have hugged her to her qualifications, she pulls back slowly, running both her hands down my now lowered arms, her hands finding mine.

"I am the hug lady. All the children tell me I give the best hugs. So, everyone calls me the hug lady," she proudly announces through a very big, beaming smile. "Now, where is yourfamily?" She asks directly and looks into my eyes, waiting for my response, as if I have a story to explain as to why I am here, in church, alone. I explain that I am a student anthropologist and give her my purpose for being in her church. I promise her that someday my family will join me, as I really want them to see what I experience when I visit, but for now, it is just me and my notebook.

"When?" she presses, wanting to know when my family will attend. "After the summer, when my work is done," I reply. She seems content with this answer but does not let go of my hands. It is as if there is no one else in the room but us and as if she has been waiting a long time to ask me these very questions. Her intentionality both alerts me to my own presence yet calms me with hers. She tells me that she knows me from the Facebook comments and posts I have "liked" and that her husband is "Pastor." Once I know who she is, I call her by her married name, Mrs. Afuom. She tells me there is no need for that, and I may use her first name.

"Why do you do this work?" she asks me. "What is your purpose?" I tell of how I came to know this community through the "Asante Gold" exhibit at the Dallas Museum of Art. She nods in recognition of the exhibition.

"So, what is your purpose?" she repeats, drawing out the word in a slow open sound that only the Ghanaian accent can master, making it very clear she wants to know my ultimate goal. "It is emerging," I reply. "I can see there is something extraordinary here in your community. I am struck by the level of dignity, the respect of the generations towards one another, the almost magical quality of the energy within the cultural events, and of course, the proverbial nature of your culture." I tell her about the proverbs I saw painted on the walls of the museum and how these mesmerized me. I explain that when I learned royals were living in the DFW-area, I had to know more about how the 
Ghanaian community lives in North Texas and still rules, reigns and thrives so far from home. I share that a sense of dignity seems to emerge from within the community, that I recognize a story here to be shared with other communities who struggle to find peace in letting go of anger toward the past, that the theme of the African in America experience, in contrast to the African American experience, is part of what emerges during my observations.

She lifts my hands to the area between our chests. She presses my fingers in her palms. "Good. I am happy you tell the real Ghana story. We are tired of people only ever recounting stories of poverty. The poverty aspect is done," she states firmly. "We have so much more to our homeland and here in our community. We are so much more. I am glad you do this work. God bless you and God speed."

I reply, "Thank you, and I agree. I feel there is so much more to Ghana."

She replies with only a firm, "Yes."

\section{What I Wear}

A group of women lingers outside of the ceremony. All are dressed in formal Ghanaian dress, two in long, snug-fitting skirts that flair at the bottom. One wears a knee-length tight fitted skirt. Each outfit is matched with a fitted top. Yellows, pinks, oranges, blacks, greens intertwined with glistening threads and rhinestones adorn their garments. I approach them and explain who I am, requesting if I may take their picture. They oblige with smiles that are agreeable yet revealing no surprise at my request.

After they pose, I ask them if the cloth patterns in their dress have meaning. They tell me the patterns represent different things for each person; It can represent a person's tribe or background. One explains that she is in traditional Kente cloth because her family is of the Asante tribe, and she is descended from an Asante King. She says this as if this is already known by all those around her and as if she is teaching a young child. Her explanation is paced, enunciating every word. I sense she does not want me to miss any of her clarification.

I continue asking, "What do the designs mean? Do they represent anything in particular? Are the colors in the weaving significant, or do they symbolize something special?" One replies, and quickly I realize she speaks for all three of them, and possibly for every woman at the event.

"The colors of Ghana represent the rich soil, the blood of our people, and the color of our tribes, but we wear what we feel. No one tells us. No one has a say. We wear what makes us feel beautiful and what represents each of us."
I take one more picture, they each smile, brighter now than at first. I thank them and watch them as they sashay away.

\section{Going Home}

The table I choose has two couples already seated. I ask if I might join them, and they welcome me warmly. Upon removing my camera from its large multi-pocket bag and placing my black Moleskine and recorder on the table, the older of the two women ask me if I am with the press. I tell her that I am not, rather I am there to do anthropological research on the Ghanaian community in North Texas. They explain they are not Ghanaian but that they each have a connection to the community. One of the older women is married to a Ghanaian man. The older man next to her tells me that he and the second lady are friends and that he is American. The second male, in his fifties, is Nigerian and married to a Ghanaian. As we go around the table greeting one another, each of them sharing their connections and their background, I remark that they each have a link to the community who is not at the table with us. They nod at my observation, informing me that two of their spouses are somewhere helping with the event, and two are not here tonight.

The older woman declares, "We come to everything the Ghanaians do. They are wonderful, won-der-ful, people!" She says, shaking her head and moving her hands to emphasize each syllable. "They are so warm, so, so wonderful!" The others nod and smile in agreement.

"So peaceful. So joyful! The music, the food. I love it when my husband tells me we have to come to something with them. Tonight, he is not here, but I could not miss this event. I called my friend," she gestures to the man to her left, "and told him to pick me up and bring me to this celebration!" The man to my left agrees with her again. The conversation then turns to issues of serving in the community, of immigration at our southern border, and of being black in America. The speak freely with me, each building upon what the other says on a particular issue.

They ask me what I think about each of these sensitive subjects; I am careful to stay neutral when providing a response. But I decide to share with them my budding theory on the historical roots of a displaced people group, how this may be a critical difference between this community and the African American community. I tell them about the difference I have recognized in the way that the two groups of people behave, and in their attitudes and worldview. Shifting in his seat to face me directly, the man to my left begins sharing his background, the story of his family, and of Ghana. 
"My name is Max, and I am the son of slaves." He opens poetically, his voice thick with a southern accent. "My great-grandmother, who I knew as a child, remembered stories of her grandmother's life in slavery. She did not talk of it very often, and so I only know bits and pieces. It was painful, and she didn't like to share the past too much. My mother would tell me what she could, but it wadn't much. My great-great grandmother knew where her family came from, but she didn't say where exactly. All we knew is she came from West Africa, somewhere in what is now Ghana."

"Not knowing was a hard thing. Family gotta know where they come from. This is something I made my peace with many years ago. But I have always wanted, needed," he emphasizes this word with a pause, "to go to Ghana, to make my peace with this last part of my journey here on earth. It was for me and my family. And last year, I did. I went home to Ghana.”

I comment on his age, that he does not look old enough to be in the "last part of his journey here on earth," and he reveals that he is, in fact, seventy-eight. We banter for a bit over my needing to know what he has been drinking all these years and how time has surely been good to him before he returns to his story.

"For a month, I went home to Ghana. I am an author. My wife, who passed away, was not from Ghana, but she was always supportive of my dream to go. I didn't go while I was married to her, and that is something I regret. But, I went this past year with a friend who has visited before. He is also not Ghanaian, but he comes here too, sometimes." (By here, I see that he means the church where we are now.)

"How was your experience?" I asked.

"It was everything I dreamed of." He smiles, nodding his head and tapping the table with his fingertips. From the look in his eyes, the expression on his face, I can tell the memory of Ghana floods his mind. "I did not find family, as I hoped. This is near impossible to do, but did I find things I did not know I was looking for. I saw different parts of me within the people. I discovered that Africa was in me all along. It is very easy to stay angry at the past, and if you don't know what you come from, it's hard to move forward. Going to Ghana helped me to make my peace." $\mathrm{He}$ continues on, reminiscing about the food and the people and the lighter sides of his trip home.

"Are the people of Ghana like the Ghanaians here?"

"They are a bit the same and a bit different. Maybe kinder here. But I know them here. In Ghana, I had to learn the people."

"Learn the people?"

"Yes, I had to learn the way they think about us and how to find my way around there."

"Did that take a long time?"
"No, they were very helpful. They like Americans, and they did not seem to mind us. But it helped to have my friend who knew his way around." Mack proceeds to tell me about the man he traveled with to Ghana, how he was asked to be an elder-advisor of a tribal community due to his Asante-kinship, and how he was even able to buy a plot of land while there. He tells about the places he visited, about standing at the shore where his ancestors would have boarded a slave ship and of the deep sadness he felt during that part of the journey. He shares with me that Ghanaians "like to have American connections and American money." He chuckles when he says this. I asked him if he finds Ghanaians to be very focused on money? He replies, "No, no. They are humble, and they are okay with having very little, but they also promote aggressiveness within their own personal success."

"Aggressiveness?" I ask.

"Yes, not aggressive in a bad way. They do not climb over other people to get places in life, but they are personally aggressive with what they want to achieve. Here, in Dallas, they are very focused on their success. They are very educated, and they get very good jobs. But it is not all for money. Their success is for the community. And family is always first."

"In what way do you mean 'for the community?"”

He explains, "They go to school but always return home to help the family. Or, they send their money home to Ghana. And, they work within the community to help others have success."

"I see what you mean. It is a different, non-harmful type of aggressivity?" I ask, attempting to summarize his statement.

"Yes, it is a non-violent aggressiveness, so a person can succeed, and everyone benefits."

"That's beautiful." I smiled.

"Yes, that is why I had to go back. I have always felt a connection to Ghana through this community. They have the same values as I do. And I knew that my family comes from this."

"Do you mean that every Ghanaian has the same values or just those you know from here?" He chuckles, "That is a good question. I will tell you this, the people that I know from here are much of the reason I wanted to go home to Ghana. I have known the pastor and his wife for over twenty years. I found the people in both places very agreeable. They are people, and they live by the standards of what they believe and, they make you feel so welcome. They love on everyone. They make everyone feel at home. We in the South like to say we have hospitality, but we don't hold a candle to these folks. It was the people here that really made it possible for me to go and visit. They had friends I was able to connect with. I didn't know a one of 'em, but they welcomed me like family, just like here." 
"I see how that could make everyone want to visit Ghana," I say. "It sounds like you had a wonderful experience, and I am so happy you had the chance to know them on both sides of the ocean." He finishes our talk by telling me that the people here are "a little piece of Ghana and a little piece of heaven, right here in Dallas.” I tell him that I could not agree more.

\section{Mother Mary}

I sit in the middle of the pews awaiting the service to start. This event was unlike the others I had attended, as today was very special. Today was Baptism Day. This was to be an ecumenical service between the congregants of the Ghana community church and the long-standing local Presbyterian church. I did not know what to expect in terms of this cross-cultural group nor what the attendance would be for such an occasion. Only being able to compare the Baptism attendance from the churches I had attended in my own experience, I did not expect it to be much larger than the regular attendee count with maybe a few extra friends and family included.

How wrong I was.

Not only was this celebration very well attended by the regular members, but there were many Ghanaians from around the community who came, and from what I learned later on, other churches and faithbackgrounds. Bringing up young people as future leaders in the community begins with bringing up the young in the faith. This appears to be a central and imperative theme for this entire community. Baptism is no small occasion, and the ceremony and celebration afterward proved that. I would spend that afternoon with hundreds of individuals who participate in and make up a good portion of the Ghanaian-DFW community. My semi-structured interviews and casual conversations would reveal a world of confident women, well-educated adults, faith-focused children, successful community members, and a faithful community of believers. But on that day, before I was allowed to exit the sanctuary to head to the celebration, I would learn what it means to be a parent, a mother, and a grandmother (Nana) in Ghana-Dallas families.

I met Mary. Nana Mary. She told me I could call her that. Standing together at the back of the sanctuary, I learned that she had been watching me with my black notebook, and she wanted to know what I was writing down. I asked her about her attire, letting her know I recognized the pattern in the fabric as Kente cloth. I told her my reason for being there, and after answering her qualification questions regarding my own faith, whether I was a mother and if I was married (to which she also inquired as to why my family was not with me) we stood and talked for a long while before going over to the celebration.
While I stood and took notes, she talked and taught. I learned that she is a matriarch in the community, and by her own account, she is the one that everyone comes to for advice. She has raised many babies, she said, and so the mothers and fathers come to her. She told me, proudly, that all of her own babies have grown to be great women and men of God and have now given her many grandchildren, which she still helps to raise.

I asked her what she thought the reasons might be that the Ghanaian community here in North Texas did not seem to struggle with the same issues of broken family relationships, crime, and demoralization as other African communities and as African Americans often do.

"Because we know how we are." She says while waving a finger near my face. "We know the shame and the pain we bring upon our families if we do something to bring us to jail. We do not do things that will bring shame to our families, our parents, or to Jesus. We raise our children to know who they are in Jesus from when they are born. We teach them the ways of the Lord before they can speak, so they always know whose they are, and who they are."

"I have seven grandchildren. Seven!" she says proudly, emphasizing the second seven so that I understand her pride and accomplishment in that number. "When my daughter had my first grandchild, we spoke of Jesus in her family and over her child. I taught her how to raise them to know Him and how to not live shamefully, but instead to glorify Jesus in all that they do. She can only raise her children to know Jesus because this is the way to harmony within the family. She reads Scripture every day and teaches them Scriptures because that is what I did for them when they were in my home."

"What happens when a child is wayward, or someone in the community has a child who gets into trouble?" I ask. She ponders for a moment and tells me, "this does not happen very often as they know the shame they bring to the family." I press her to think of a person or a situation where this has happened so that I can ask my question again. She instead tells me that "In Ghana it is different. There is crime, though not bad crime. It is petty crimes, but it is safe to travel down the street. But here, when you come to America, it is not like this here. We must live better here than we do at home." She leaves it at that to tell me more about the raising of children and grandchildren in the Scriptures. I make a note to find others to ask about wayward children and adults who may have brought shame upon the community.

"They must learn the Scriptures," she says. "This is what guides them to not make shameful decisions. Ask any child here," she makes a gesture with her arm as to say I should challenge any child on the property to prove her wrong, "and they will tell you the Scriptures. 
They are taught to them their whole lives. This is how we are. We are people of Jesus Christ, and we know him for all our lives. We raise our children to know Him as Lord and Savior, and so they have good lives and make a good way for their family."

I cannot count the number of times her conversation has brought up Jesus as the antidote to shame and shameful decision making. While we are talking, there are others nearby, some listening to our conversation. I look to their faces to see if they agree or show signs that she is an outdated old woman who does not know what is really going on with the young people of her community. Many of them nod, when she makes a point they agree with, and as we end our time together, we hug. As we do, a lady in her mid-thirties shimmies in between the rows of pews where we are standing. She has a baby strapped to her back in a bright and colorful African print cloth. She is dressed in Kente cloth skirt and blouse, as well. A young toddler clings to her leg and a young man, I estimate at about age eleven, walks behind them, his long fingers touching the top of each chair as he approaches behind her.

"This is my daughter," Nana Mary says, her smile beaming from ear to ear. Her daughter smiles and shakes my hand but shows no further interest in the conversation she has previously overheard. She says something to her mother, her tone changing to show she is talking about something logistical and pragmatic. The young toddler presses into her mother's skirt and makes a little stir. Without a word, the pre-teen boy exits his row in the pew, comes down into the row in front of where this woman is standing, and scoops up the toddler; No instruction from her, no fuss from the child. He walks away, cupping her in both arms and talking to her and another youth as he walks by.

"What a good boy your son is," I say to Nana Mary's daughter.

"Oh, he is not my son. He is only the son of a friend."

"Wow, he is a natural with children," I reply.

She looks to where the boy is walking away and makes a small "hmmm" sound as if she is thinking. I get the strange feeling she has never noticed that his behavior may not be the norm for youth his age. We both watch him exit with the toddler and several other children in tow.

I look to Nana Mary and realize she is watching me closely, "See, this is how we raise our children." Point taken Nana Mary.

\section{The Coronation}

Trying to apologize in hushed tones to everyone that I pass, I attempt to show the utmost respect for my tardiness and for disturbing the event. I try to bend low as I walk by and hustle to stay close to my guide. We are nearing the front of the room. I begin to feel a slight panic when I see there are only twenty more chairs or so until the end of the front row. In just a few more steps, I will be at the very front of the event where tribal royalty is seated and who I think I recognize as two Asante chiefs. It is just then when my guide begins to slow down, turns to me, and shows me to the man I am to be seated next to, my translator and guide for the evening, the man who is also holding the microphone and at the center of the event. My informant is the coronation emcee and host. I feel the color drain from my face as my guide waves to the emcee, indicating he should stop what he is doing and come over and meet me.

Which, he does. He pauses his narration of the event and walks straight toward me. When he reaches me, I smile and thank him profusely, apologizing for my tardiness, which he waves away as if to say it is no matter at all. Here, while a coronation is taking place behind us, he greets me as if I am a long-lost friend. The ritual of the ceremony continues on, the waving of the feathered post, the bending and prostrating men in the center that never stops, and after the emcee moves me by the hand to my seat, only a handful of seats away from the front of the stage and tribal royalty, he returns to his duties.

There I sit, in one of the biggest cultural events of the year, with what I estimate to be at least seven hundred and fifty people, maybe a thousand people, in the room (I quickly calculate that this room is holding $10-15 \%$ of the entire North Texas Ghanaian population), and I am seated at the very front, facing them all. I am wearing a semi-formal dress and say a silent prayer of gratitude that I listened to my informant when he told me the attire was "black for Ghanaians, but I could wear whatever I like.” I was in black.

Members of royalty are adorned from top to bottom in headdresses and head wraps, yards of black cloth, and bejeweled with gold. The women are striking in dress and stature, and the men hold themselves with such ease, yet regal regard. Posture is rampant in this room as people rise and sit between the various stages of the ritual. They walk as if they are all kings and queens.

There are several men, the soon to be crowned princes' royal advisors, who must come before the chiefs to pledge loyalty and to be approved as such. With each, there is a procession: a royal umbrella, bending and prostrating, a series of bows and speeches to demonstrate the loyalty of the heart of the man in question. Then, each completes his tasks and is approved by the leaders, who confer at the front of the room on the temporary royal dais. There are more drums and hearty handshakes, more processions, and buckets of baby powder sprayed on the backs of the now accepted and approved advisors by the royal 
women in the crowd. This happens four more times before the prince is ready for the coronation and the final procession of the night. I marvel at how they have made this Dallas wedding and event venue feel like I am actually in Ghana.

As we proceed through more chanting and drumming, dancing, and powder, it is finally time for the big moment. All of the procession steps are the same as the previous; only they move slower, more intently, and with much more fanfare. More people crowd around the prince as he appears, brought into the room from the back center doors, framing him under an even larger ritual umbrella. He, too, is in all black, rich, thick cloth with a sheen fit for royalty. Yards of fabric are wrapped around his waist and thrown over the left shoulder as he proceeds through the crowd to his place before the dais, facing the tribal elders. He slips off his slippers, like each of the men before him, prostrating himself before the rows of men and women on the stage. Following the ritual formation, he is led around the open area in a series of movements and choreographed actions. He declares his character in several speeches and completes the ritual phases with large sticks and feathers and more prostrating. I capture all this activity on page after page, recording every sound and movement on camera, when something happens.

From the stage, an elder is up off his chair. He speaks directly at the prince in a foreign tongue. He sounds angry. His voice quivers but grows with volume. His hand points angrily at the prince as he fires one question after the other. The emcee, my translator, is communicating what is taking place as fast as he can, often relaying to the audience what is being said. The prince listens respectfully, and when the old man is done, he pauses a moment before he answers in refute. He never raises his voice as he speaks. I almost jump when the old man stops him at the end of his humble retort, shouting at him and raising his hands as if to say, "Off with you!" He is loud, and I am astounded at the anger and sudden outburst. The emcee is watching the situation but no longer translating. I look around to the royalty seated near me and see that some are nodding with the man as he speaks, some are stone-still, and a few of the women lean in toward one another, whispering out of the sides of their mouths.

I ask my informant about what is happening. He tells me, "The elder has a problem with the honor of the prince because he makes choices that are unsavory for our people. He has doubts as to whether he will make a good leader because of his choices."

I wonder what these unsavory choices are, and my mind begins to wander. $\mathrm{He}$ is a large man, not overweight, but built like an athlete. He is handsome and looks to be strong. I think he must have cheated on his wife or had a family scandal of some sort. That must be it, I think, for all this drama. My mind imagines all sorts of scandalous scenarios as I watch this vehement exchange between the old man and the young prince. After a few more minutes of the old man shouting and pacing as best as his aged body will allow, and the young prince answering with a steady, unwavering response, the man shouts once more, bangs down his staff on the back of his chair and leaves the platform. He walks down the steps right past the men surrounding the prince, storming out of the room, all the while muttering under his breath.

No one chases after him, and oddly, the room quiets down quite quickly. I am astonished at how little reaction the crowd has had to this situation. Some have smug looks on their faces, others nod to each other as if in solidarity. The host, still seated next to me, watches the rest of the royal leaders as the ritual proceeds. There is more discussion and conferring than with the previous men, but in the end, the drums sound, the powder flies, and the prince is crowned.

When my informant has slowed his celebration of dancing, shaking hands, and embracing the women and men throughout the room, I ask him what the situation with the chief was about. I steady my pen and paper to capture the story, just knowing this will be the crack I have been waiting for in what seems to be a people of perpetual goodness.

"He is angry at the boy because he did not complete a contract with him for a piece of land." I find it odd that he calls this grown prince a boy, and I ask him about this. "He is a boy because he has known the elder for his entire life, and he is knowing his family as well. They are family, they know each other many years, and their families go back many years," he explains.

"So, that is all that he did? He only skipped out on a contract on some land?" I realize my disappointment makes my response sound crass.

"No, he did not 'skip out.' He did not purchase the land, and he gave his word that he would."

"So, he changed his mind?" I ask, sounding more doubtful than I intend to.

"Yes, but he gave his word," he retorts with a tone, settling slowly on the phrase 'gave his word' that informs me that there is a lesson here.

"And so, when he was defending his character in the ritual, this was a problem because there was this issue of his character," I say to show that I understand his emphasis.

"Yes," he replies, "it is an issue of honor for a man to not do what he says he will do."

"Why were the people not upset with the chief's outburst?" I asked. "Would it have been possible that he would not have been crowned if the leaders resisted as a group?"

"No, this would not happen. The hene (leader) was just taking the opportunity to show why it is important 
to be true to your word and to tell the community that this has happened so that we may be watchful for future issues . . . and the community of his council, the men who will advise him will know he has this weakness." I hope to speak to him longer on the subject, but he informs me it is time to change our clothes into our white attire so that the big celebration may begin.

"Now, you must get ready in your white dress and come back so that we can show you the food and the way we party in Ghana.” Just like that, a coronation, celebration, and a life lesson all co-exist.

\section{Patterns Revealed}

What occurred at my first visit within the walls of the Ghanaian Presbyterian Church would set the tone and stage for the rest of my research. With each new interaction, I recognized patterns which, though rooted in Ghanaian teaching and culture, evolved into a unique reproduction of group identity for those living abroad. These patterns are the influence that genealogical and historical roots have on a group's temperament. Identity, the understanding of life and community when a sense of belonging arises from one's ancient past, leads to unity and dignity as a path to peace and joy, and is expressed through the network of associations, churches, and cultural events.

In every church gathering or community event, these patterns were highlighted in behavior through their reappearance and repetition. The recognition of these patterns, and their distinguishing nuances, illustrate what one might come to know when immersed and living in a foreign place. The following is only a sample of such patterns:

Gender Equality. Time and time again, I saw a demonstrated equality of leadership with regards to gender. Yes, women grouped together to serve food, but it became apparent this was as much a structured time of social life as was the men's work of setting out the tables and chairs-which I saw both children and women assisting with as well. Several times, it was made known to me that a man had made the dish his wife or sister was serving. I did not observe subservience or gender stratification. If a person spoke and he happened to be male, his authority as pastor and community spokes-man was the supreme reason, not his gender. In many associations, women served as equals in rank, position, and voice. There is a comfort between the genders that is respectful and honoring- it is respect for the gender, yes, but even more so, for the person. Women do assume dominant female-centric activities, yet it was common to see the hand-off of childcare to a male partner or male teen without so much as a request for help. Babies and toddlers slipped from hand to hand when a change in care providers was needed or when the mother had to remove herself for a time. I never once saw an infant or toddler cry for their mother when this hand-off took place. This leads one to believe that this is quite normal among parents. I was informed by both men and women that there are roles they fulfill, not out of obligation, but out of natural proclivity, yet there is never a problem with asking the opposite sex to step in. This is never more apparent than with the number of teen boys I witnessed as caregivers for young children. It was more than common to see a teen boy with a baby on his hip. The gender walls are invisible amongst the youth as well. Girls did not congregate only with girls, nor boys with boys. At all times, all children of all ages moved freely about both in play, childcare, and in tasks and chores at events and services.

Relationships between tribal affinities, economic status, and educational/career attainment followed this same rule of thumb. In the high structure of association meetings, which held to not-for-profit rules of order, there were positions such as president, vice-president, secretary, treasurer, etc. Even here, women and men served where they were needed and had a natural propensity. Where there was not yet a skill, as with the young, the older children helped the younger children to learn it. I observed several older teens instructing and guiding younger teens with a variety of tasks such as caring for a toddler, setting up a room for an event, cleaning the kitchen, and preparing the sacred objects for the altar before a service.

Missionary Mindset. There is a sense of celebration, a piece of "heaven here on earth," that only those who know what it is like to live outside of their homeland community will understand. Having lived outside my own country for many years, I have experienced this unique situation when one meets a fellow countryman in a foreign place. I witnessed this same joy in the Ghanaian community, at their events, time and time again; It is as if they are greeting one another in heaven, every time they meet. Their enthusiastic and heartfelt joy is shared as if the friend has long been lost. Their praises to God, their sharing of Scripture in everyday conversation, and their sheer delight when a new or fellow believer is in their midst was usual business.

References to Ghana. In every conversation, every sermon, every speech, Ghana is there. It is not an impression through nuance or a background reference. No, it was always prominently placed and referred to as often as possible. I began to count the number of times in which Ghana was referred to within sermons. On the low-end, there were three references. The winner was nine. And each time the reference was well placed within the context, expressed seamlessly within the 
message. These references are often met with head nods and affirmation through the group's body language; and a couple of times there was a "hallelujah" or a "Yes, Pastor" in reply. I asked one of my informants about this, and he shook his head as if he agreed with me. "Yes, it is always Ghana, all the time. We will not lose her."

Academic Interest. I was struck by the number of times and by the variety of people who asked me about the theme and thesis of my work. This level of academic inquiry is unusual in large groups. I was frequently asked by individuals, ranging in age from mid-twenties to late eighties, about the purpose, finding, and thesis theme of my research. Most of the inquiries accompanied a suggestion of a dissertation, paper, or a professor's academic book I needed to read. This rare phenomenon, rare due to this population not being directly tied to an academic community, led to a wealth of information, and many of the reading suggestions became the literary foundation for my research. The contributions furthered my information intake process, meaning that I sought out dissertations and research that I otherwise may have overlooked or not been aware of, and the academic atmosphere altered the depth of my interviews, as well.

Duality. In most everything I experienced within this community, there is a duality at work. This is not a duality of opposition, but a symbiotic relationship between two worlds, two eras, two parts of history. As can be said for all people groups, Ghana is not Ghana without its past. Yet, Ghanaians, unlike many peoples, are not haunted by the repressive, dark layers of their history; it is a past that is worn on their sleeves, but not one bridled by anger and discontent. It is as much a part of their character as anything else. The irony is found in the way that they do not hold the two worlds, past and present, in a negative or positive light. They carry all that makes them who they are as just that: the fibers of their being, something to build upon, and remember, yet neither to be heralded nor scowled upon.

Where other peoples have felt the weight of their fettered chains for hundreds of years, the migrant population of Ghana recognizes the oppression of their past within their story, and lives alongside and within the freedom from this oppression as part of a 'beautyfrom-ashes' narrative. There is no call to rise above, to shed the past, or to break away from the shadows that haunt them, for they are not haunted. The things of the past have affected them profoundly, yet they have found a way through, and they are who they are today because of these influences-fully Ghanaian with all of its markings, color, and scars. There is no easy way to explain this phenomenon, yet within it lie great lessons to be taken into further anthropological study and other research fields.

Spatial Diaspora. Immigrants normally live in a spatial diaspora that fosters mythical or utopian images of both places (Canaporo 2006, 6.) But there is an understanding in this community that Ghana is different for them now that they live overseas, and it will be different for their children who know of Ghana only from the stories, short visits to the homeland, and community gatherings. Gupta and Ferguson suggest that, "remembered places have often served as symbolic anchors of the community for dispersed people. This has long been true of immigrants who ... use memory of place to construct imaginatively their new world. 'Homeland' in this way, remains one of the most potent unifying symbols for mobile and displaced peoples, though the relation to homeland may be very differently constructed in different situations" (1992, 376). It appears, at first glance, that homeland is the connector within the community and rightly so-they are Ghanaian, this fact connects them. Yet, what is missing from this construct is a sense of longing, of desperation, or a clinging to a past with which they can no longer participate. This 'need to remember' is not founded on the threat of loss or displacement that Gupta and Ferguson identify.

Ghanaians have known travel to other lands as part of their history. But they leave not because they were threatened or displaced, rather for their own cultural and economic development. The experience of leaving Ghana to learn, to work, to visit, may be so ingrained that the model of creating the new longed-for place that Gupta and Ferguson describe is not part of their immigrant experience. Yes, they educate their young, along with the outside community, about Ghana, but it is not to create a new world here or a utopian view of the homeland. They live very much within the American lifestyle participating in Western activities and the larger economy. Their teaching about Ghana is designed to provide cultural history, knowledge, memory, and herald the homeland, and it is open to everyone, not just the immigrants themselves. That openness to all is a significant point of difference from other communities who reside in North Texas as a result of displacement. DFW-Ghanaians seek opportunities to bring outsiders into their festivities and to partner with local entities in those efforts. Their concept of building community is not exclusive in nature, but collective.

Ghanaians don't view themselves as exiles from conflict or displacement. Instead, I was informed often and regularly, that "America is the dream," "the land of prosperity," and since "Ghana is not a war-torn country like other African countries ... we can easily come here to make a better way for our families and ourselves.” 
They view themselves as being in transition, and they find a way to live and thrive in the DFW Metroplex while not sacrificing the cultural elements they know represent Ghana. In line with the duality-principle mentioned above, work, social placement, education, and profession success, are just as important as family, cultural values, and language retention.

This duality demonstrates a response to anthropological questions of interconnectivity, space, and belonging, but it is also arguably the result of the importance of the roots of Christianity in Ghanaian life. For this group, national identity is part of the community framework, but Christian values and beliefs are more important. The influence of Christian belief and practice is evident both with those within the community and with those looking for connection to the community.

Collectivism vs. Individuality. Cross-cultural psychologists study the similarities and differences between individualistic and collectivist cultures. One study, conducted by Ma and Schoenemann (2010), found that while 60 percent of Kenyans (a collectivist culture) described themselves in terms of their roles within groups, 48 percent of Americans (an individualist culture) used personal characteristics to describe themselves. After reading this study, I spent much time looking for this polarity within the Ghanaians I observed. Yet, it confounds me to say that instead of confirming the research and typical traits of Westerners vs. Africans, my subjects showed a true duality once again: they are both collectivists and individualists.

In listening for linguistic cues of "we" versus "me", I could not find a pattern of dominant speech. When my interviews were mainly with male church leadership, I thought I would discover a difference from when I spoke with the women, both in leadership and nonleadership roles. Instead, I found the same patterns: "We" was reserved for the descriptions of the group, their heritage, their customs. "I" was used when speaking of the reasons a person left Ghana to move to America, what they felt about their job, and how they spoke of their families, children, and parents. This dichotomy was apparent not only when talking about self or the community but also in discussing their politics back home and values for their community here.

This sense of personal identity in collectivity, of knowing who one is and to what one is attached, as well as knowing one's place and influence within the community, is an exceptional quality in the cultural patterns and personalities of the people I studied. The ability to know one's place, and to make efforts to ensure that the young people in the community have a place and a chance to develop both within that community and within themselves, is crucial to any person developing into a healthy member of society. Generativity (Erik Erikson's term for concern for the next generation) is strong in the Ghanaian community and reflected in the knowledge of self, the knowledge of the community, and then the knowledge of self with and without the community, as well. The Ghanaians' success at achieving this balance could be due to the level of careers and education the community members attain. As well, a sense of personal independence allows for the choice for community to be made freely, and not forced. In most studies and research on high generativity and identity certainty, the individual experiences a well-balanced perspective on life and of the self. There is usually low anxiety, little fear about the world around them, and low personal crisis or at-risk behaviors (Santrock, 2018). It was interesting to me to witness this en masse within a group that embodies these principles.

Historical Influence on the Present. This has proved to be the most difficult element of duality to describe, not to mention that the burden of proof can only be discovered and witnessed within the space of ethnographic involvement. Yet, I will attempt to trace the links between past and present in terms of Ghanaians' principle of duality as it has expressed itself in their history.

Before the colonization of the country we know as Ghana, there was a realization that the colonists could not manage the warring tribes and their relationship to the colonial representatives. Ghanaian leadership, therefore, presented themselves as collaborative leaders to colonial authorities, suggesting that they manage their own people for the colonial kingdoms that had claimed the land. This method of shared leadership was implemented, and it brought forth elements of colonialism not experienced in other parts of the colonized world. Yet, this was not the first time this strategic move was made in Ghana's history.

Ancient tribal history tells tales of collaborative leadership within tribes in sub-Saharan regions as well as intertwining the management of the Ghana, Mali, and Songhay empires (Conrad 2005, 11-23). This pattern of convincing ruling nations to allow tribal leadership played a part in trade revenues, gold distribution, Islamic influences, tribal rivalries, and more. Sadly, this same mindset played a large part in the slave trade of the Gold Coast as well, when Ghanaian and rival tribes contributed to the sale of conquered humans to their colonial counterparts.

Still, one cannot deny the astute political craft Ghanaians employed to gain and retain some sense of ownership of their own lands. One of my informants, a highly educated woman with a role in leadership within the community, told me that this is one of the reasons that Ghana does not see war in their country as often as 
the rest of the world, nor do they perpetuate war. For the sake of this paper, a deep dive into this untested theory is not possible. Still, it represents the recognition that they are aware of their place within a leadership structure and how it affects the outcome they desire, despite perceived or real limitations.

To better explain the situation, a comparison is required: In many Texas-based Protestant churches, it is not uncommon to have a secondary church community-for example, a smaller Black, Hispanic, or Asian church-rent or lease space when it is not in use by the leading congregation's activities. This is not what is happening in DFW-Ghana church partnerships. Ghanaian groups are accepted as part of the larger community within which their ministries and community activities reside; they are not just lessees on a rental agreement. They have utilized the historical pattern of their past in partnering with present-day congregations and larger church campuses to bring them into shared leadership. This might be seen as an anomaly if it was just one or two of the congregations, but in every church I visited (if they were not owners of their own property), this cohabitating relationship was the norm. When I brought the recognition of this pattern to their attention, all of the lead pastor interviewees agreed they had had the same experience. One stated it best, "You are right! There was never a time when I felt as though I could doubt their belonging here on our campus. Pastor Paul made a case for their being here so compelling that our church knew it was a no-brainer, and now we lead worship together, often.”

Kinship and Tribal Affiliation. As I presented my questions on tribal affiliation to my first few informal and formal interview subjects, I sensed they answered my questions as if they were checking off a box. Quickly they'd tell me their tribal connection or affiliation and then move on to other information they deemed more vital to our conversation. Tribal roots are important, but not to the extent that they dominate the choices made within the community. One does not move according to kinship or tribal affiliation. Job placement, housing costs, and schools are more important in affecting the outcome and location of residency. The distance from the group or parts of the group is not as determinant as proximity to their jobs or churches is. They stay connected to those with whom they share a language or regional affinity through associations and community activities. Thus tribal affiliation does not limit one's involvement in other communities; as one person put it, "It is not uncommon to eat a meal at a table and not know what they are saying." It seems boundaries are crossed with ease here.

Another pattern emerged when asking about their tribal history. Almost all would tell me if they had Asante, Ewe, or Ga roots, but they never told me if they were royalty or not. Someone else would inform me later, and they would do so without much fanfare as if it was almost an afterthought. During many of my conversations and interviews, subjects made a point to inform me if they had married a Nigerian, an American, a Jamaican, or another outsider. There was something important about this part of the discourse, as if the idea that they know who they are, yet they do not deny themselves the world when it comes to love and life, was an important factor. "My name is Hope. I am from Ghana, from the capital of Accra. You know, Accra? It is in the southern coastal region. My husband is from South Africa ..." Never stated with pride, but more as if they thought this information would add layers of understanding to the information they were providing me. "Are you connected to a specific tribe, Hope?" "Oh, yes, I am Asante." It was Hope's female companion that told me later that Hope was an Asante princess.

Knowledge of their ancestral roots is important to who each person is, how they express themselves within the community, and to outsiders. Yet, that same reflection is turned inward in the attempts to live within several African or other cultural affiliations. There was a humble pride when they shared their mixed family relations. What is most interesting in this revelation is how the Ghanaian portion of each coupling did not lessen or become dormant.

Unity. The concept of unity permeated the Ghanaian community. Though that unity starts within the family that left Ghana, it also extends beyond it. Yet, the acceptance of all peoples is important to their personal statement of who each person is and how that reflects upon the community as a whole. Though their community celebrations and worship groups are predominately Ghanaian, the feeling of being welcomed and accepted is experienced from the first step through the door, as if one had always been in their midst. This welcome is the basis for the greater sense of unity. Kinship is important, but unity between one another as human beings is a crucial element.

Character. "A diseased vulture never parts company with the rubbish heap." Ghanaian Proverb. Theirs is a modest and pious approach to life seen in each man, woman, and child. Never did anyone exhibit any sense of shame or a devalued state of being because of the color of their skin, their impoverished and often struggling homeland, or their slave-ridden past. And though they bestow an unassuming peaceful demeanor, they carry their heads held high, have eyes that are bright with life, smiles that are strong and engaging, and a hand that is offered first, in every encounter. No sense of fear is found in the presence of even the youngest person, as even the children appear comfortable within 
their space, and form and exhibit a tangible trust in the community, and even with strangers like me. Why this comfort and ease? How this pride and confidence? Is this because they know, or believe, they are descended from a people known to have had unmatched power and wealth? Do they retain a sense of regality because their history impresses upon them the empire they are descended from? Is it this knowledge of their ancestral history which gives them a sense of who they are, even when they live among strangers in a foreign land? With all they have been through, slavery, oppression, government upheaval, and colonialism, they move freely within their new homeland with confidence.

Geertz recognized there were only a few decolonized, though not completely, populations that did not live caught within the tension of postcolonialism $(1973,240)$. This very rare phenomenon occurs, he said, because tensions of past and present do not "[invade] every aspect of national life" (240-241). I am convinced that the subjects of my fieldwork provide evidence that this is so. In fact, Geertz recognized that Ghana was one of these principalities (238-239).

When I compare other communities who feel they descend from that kind of power, prestige, and divinity, there is a sense of pride and ethnocentrism. But one does not recognize any kind of self- aggrandizement in these emigrated Ghanaians. The proud Ghanaian is not putting on airs, for they have known who they are for centuries, and their circumstances, for better or worse, do not change that reality. Nor, do they fight that history. They are descendants of kings, of one of the greatest empires on earth. It does not matter that they were conquered, uprooted, sold, divided, or ruled, for they survived and overcame time and time again. They know who they are descended from, and their proud spirit is not derived from the power of others or from proving to the world who they are. Instead, this knowledge of self is demonstrated in a calm and collected manner.

A sense of knowing who one is, where one comes from, and a shared collective meaning beats at the innermost heart of culture throughout history. Though the history of the Ghanaian people has been contested within archeological and historical circles, they themselves know their history (Conrad 2005, 17-22). It is both an oral and written history, with the oral being the more dominant of the two. It is this 'knowing' that is the key to their success compared to others in similar circumstances and to their ability to adjust to life in America. Robben states, "people must first make sense of their own culture and then find the right discourse to explain it to a foreign ethnographer who lacks any lived experience in the community under study" (Robben 2012, 514). What I found with my subjects, though, was a completely relaxed approach. I did not experience my subjects striving to explain themselves through strained discourse. Their approach to an explanation was through example, story, and a matter-of-fact approach to answering my questions. They simply have nothing to prove, and though they profess a belief in Jesus Christ as a passion point in their lives and community, even this was shared through example instead of forceful persuasion.

What is missing from the subjects I interviewed and within the community was resentment, anger, fear, anxiety, or distress. Passionate conversations and loud voices of protest at association meetings and coronations are not silenced as they are often voices raised to protest issues such as the lack of character of a soon-to-be tribal leader or on subjects such as sex education tainting the young minds of Ghanaian children both in Ghana and in the United States. The most common and passionate outcries were attached to calls to action in reminding the community of their role in raising young men of character and in teaching the ways of Ghana to the young in their community.

As a Caucasian woman, I press into my final thoughts with a humble stance, not as one who holds the answer to the difficult issues of the race relations which plague our nation and the world right now, but as one who has been afforded the blessing of insight into underlying matters around the race issues we face through the observation of this community. Through my research, I garnered enough trust and connection to allow me to inquire about the issues of race, racial mistreatment, and inequity in the different experiences of Black Americans and of Africans in America (specifically the DFW-Ghanaian community, though I recognize that other African immigrant communities have their own unique experiences which deserve representation). In asking my informants about this difference, I obtained a composite answer that goes back to this issue of roots and the knowledge of who one is. It leads to a belief and theory I call, blank genealogy. Migrant Ghanaians, though hailing from a country whose past and present are plagued with extreme poverty, multiple administrations, political coups, and an atrocious slave history, do not carry with them the same heaviness as their stateside contemporaries. Somehow, they have found a way to live within their tragic, marred past without denying their history or the loss of so many of their people. And from within this space, they move forward in positive and constructive ways. I suggest that their understanding of personhood, being connected to a systematically supportive community, is cemented in a pragmatic understanding of historical roots and religious identity. Theirs is both a teleological and deontological existence of purpose and ethical choices that are shaped by their past but not held captive by the darker side of history. The historical, genealogical timeline of non-migrant 
Black communities in the United States tragically stops on the shores of the Gold Coast. The generational trauma of being ripped from and stripped of one's roots leads to a profound sense of loss and demoralization that has produced rage, long-term trauma, and desperate acts to have one's voice acknowledged, valued and heard. This blank genealogy of many African American people has led to a very different experience from that of Ghanaians in North Texas.

In addition to the split in historical timelines of a once connected people, I believe the commitment of DFW-Ghanaians in and to the values and purpose of a professed Christian lifestyle has shaped their dual existence and brought about a sense of identity that is rooted in a greater historical connection than only to one's homeland. "Moral life is not comprised of beliefs plus decisions; our moral life is the process in which our conviction forms our character" (Hauerwas 1983, 16). The connection to their history and link to their faith have produced a character in the Ghanaians of North Texas that can have significant implications for the church and its role in helping to heal our broken nation.

\section{Implications for the Church}

Roots. My research and subsequent discourse around the example of the well-led lives of DFWGhanaians leaves much more to be discovered and addressed. If left only to anthropology, these discoveries and implications might remain as fieldwork peculiarities, warm-hearted and lovely, but still only characteristics of a particular people. Yet, the perspective that I have offered here, as opposed to some of the standard anthropological views, is in part to make my point that there are implications for the church and the global body of believers. Intended as a prescriptive anthropology, of sorts, this fieldwork can help to bring about, on a much broader scale, some of the positive qualities recognized within the habits and lifestyles of DFW-Ghanaians.

As previously stated, I am a Caucasian woman raised within the confines of that description. I am one who can look into a black community and understand only as deeply as my intentions, and my efforts at an unbiased mind, can take me. My experience will never connect fully to those who have been oppressed due to their skin color and past. Yet, what I have witnessed within this community, that graciously allowed me into their midst, is a message I feel compelled to deliver to others, especially to the church.

The difference between the Ghanaian community and that of the African American experience is not a result of differences in character or attitude towards the past and present; it lies specifically in the knowledge of one's roots. Roots and connection are at the core of the human experience for everyone. Humanity is nothing without its history and story, and people without the full knowledge of their past are both debilitated and handicapped. It is the worst kind of generational trauma. Not knowing where collectively one hails from leaves the soul of a people impoverished and broken. This statement does not mean that the Black slaverooted population of the Americas has not risen to its own level of dignity and wholeness; I merely, and humbly, note that parts of their history are forever-lost due to the tragic impact of the slave trade and that this has had impact on their sense of confidence in who they are (Hartman 2007). Still, living with a blank genealogy has a damaging effect that a knowledge and an understanding of adoption into God's family can remedy.

The church has a unique gift to offer the world with the story of redemption and unity. Through being grafted and adopted into a larger family, one belonging to God, we find connection. This is the story of humankind, as Christianity tells it, and it calls out in response to the need for roots and connection that lost and displaced peoples throughout the world have experienced. Specifically, for this community, roots, as being grafted into the Body of Christ as adopted sons and daughters, is what gives the deepest of connections. Knowing one's history in Him, when one's past is unknown or rejected by society, makes it possible to live within a settled, unified, and peaceful sense of identity, both collectively and individually. Church leaders can focus messages and teaching around this subject of adoption, of being chosen by God, of freedom to develop and grow as a unified people when ministering to displaced and genealogically disconnected persons.

Future: Who people should be. How we should portray ourselves. How we should live as men, women, and children. This is the 'stuff of sermons' heard all over the world. Yet, among my research subjects, this conversation is not reserved only for the pulpit. It is normal conversation at every junction. How we choose to represent ourselves and our community, how we love and serve and live within the unity of spirit is rightly within the church's vocabulary, but does it permeate every gathering? Does it seep into every conversation parents and grandparents have with their children? Does it allow for adults to hold one another to task when one has fallen short of the values in life? In this community, it does. Where we might err on the side of being afraid to talk about proper religious behavior too much, Ghanaians living in North Texas speak of it all the time. There is a sense that they are all missionaries within their own spheres of influence.

One can safely assume this may be a reason they experience the benefits of closer family connection, less crime within their localized community, fewer mental health issues, and a greater sense of connection to the 
community and the goals of the community at large. The church can learn a great deal from this pragmatic and constant approach to reminding its members of how life as a believer should be lived.

Hauerwas states, "We are destined to discover ourselves only within God's history, for God is our beginning and end" $(1983,29)$. Ghanaians in North Texas see themselves, both as individuals and as a collectivity, within God's story: from beginning to end, biblically and historically unto the present day. They see their purpose and meaning within the timeline of God's history. Undoubtedly, this larger view has impacted their community for the better. The church can, and rightfully should, recognize this 'back to the basics' mentality, as it could provide church leadership with what has been missing in dwindling Western congregations. The faith of these Ghanaians, not based on congregational programs or an entertaining display of the Gospel, is a living example of knowing their purpose within the story the Gospel and of living this out through deed and word throughout the entirety of the population. It is the individual choice and action of each Texas-Ghanaian, compelled by a personal commitment to Christ, and an example of the community to the larger Christian church.

Contrary to many an anthropologist of religion, I cannot subscribe to the theory that religion's purpose in this community is simply to be the structure that brings about more cohesiveness or morality to the arrangement of social relations. The religious beliefs and lived-out examples of steadfast faith within this group are not tools of a well-functioning social machinery. Rather, it is their commitment to Christianity that gives this group a story with both a past and a future.

Mission Mindset. Realizing that there may be social differences between the group of Ghanaians living in North Texas and those they left behind in Ghana, it is possible that migration requires a specific mindset. It is my observation that there is a certain mission-mindset which prepares hearts to go, and also attracts particular types of individuals to the idea of moving. Crime is unbiased. It travels well, and it travels across borders every day. Yet, this issue, along with other adverse societal problems, is not prevalent amongst this population. One should not assume that this land of the free compels right and ethical behavior, as statistics would prove otherwise. I believe that the call to move, to garner gainful employment, and to thrive in North Texas is found in the type of mission minded persons who are attracted or compelled to make the move overseas. The high rate of Ghanaians who are involved and regularly attend a Christian church in North Texas would seem to support this possibility (Pew Research Center, 2019).

\section{Conclusion}

As a Christian anthropologist, I find the study of violence prevention and peace perpetuation vital to the work to which we are called. When I entered into the world of Ghanaians residing in North Texas, I believed I was about to commune with an ancient migrated tribal community, one which would provide me with the elements my anthropological texts prepared me for: stories of ancient civilization, pottery samples, food tastings, kinship, tribal charts, symbolism, social structure, trade, and economic understanding. Instead, I found a community that removed all my previous understandings and provided me with a glimpse into the world as it could be. As a result, I am now developing theories and exploration around blank genealogy and prescriptive anthropology.

There is a love of nation, yet a break from the societal norms of exclusive nationalism. There is a remembrance of oppression and violence, but it is not a weight that limits their positive experience moving forward. There is a call to unity, shown through the continual respect for self and others, which dignifies every member of their group, from young to old. This mindset gives each person standing within the community, and they know their personal responsibility and what is involved in that role. Living in the Texas landscape helps not to create a utopia, but a community that chooses to live with the highest of standards and set an example of a well-lived life for others. These people hail from strong religious backgrounds, rooted in Judeo-Christian beliefs. A missionary mindset, one of sharing the message and values of Jesus and the story of God's hand in humanity, is a critical marker. The knowledge of where they came from, in whom they are rooted and connected, both in faith and ancestry, is the most significant identifiable factor in their strong community life.

This example of connectedness through unity, equality through dignity, and peace with the past sets in motion future conversations and discourse over subjects which less favorable societal circumstances have rendered difficult. There is much to learn in the example given by this community of Ghanaians. Further fieldwork might discover, and uncover, more information about how to replicate and share that which is working so well. Giving new and further voice to the leaders and members of this group would help to perpetuate many of the positive qualities they exude. The church should take heed and inquire as to why this community radiates much of what is taught on Sunday, in their daily lives. The world should also look and listen to the Ghanaians of North Texas to see what is working and inquire as to why. 


\section{References}

Canaporo, Claudio. 2006. The Notion of 'Spatial Diaspora' and the Geographical Location of Knowledge. Research Network Migrations, Diasporas, Identities. URL: http://www.canaparo.org/Pdf_files/paper_diaspora.pdf.

Conrad, David C. 2005. Empires of Medieval West Africa: Ghana, Mali, and Songhay. New York, NY: Facts on File, State University of New York.

Geertz, Clifford. 1973. The Interpretation of Cultures. New York, NY: Basic Books.

Gupta, Akhil and James Ferguson. 2012. Beyond Culture: Space, Identity, and the Politics of Difference. In Ethnographic Fieldwork: An Anthropological Reader, Second Edition. Antonius C. G. M. Robben and Jeffrey A. Sluka, eds. West Sussex, UK: John Wiley \& Sons.

Hartman, Saidiya. 2007. Lose Your Mother-A Journey Along the Atlantic Slave Route. New York, NY: Farrar, Straus, and Giroux.

Hauerwas, Stanley. 1983. The Peaceable Kingdom-A Primer In Christian Ethics. Notre Dame, Indiana: The University of Notre Dame Press.

Ma, Vaunne and Thomas J. Schoeneman. 1997. Individualism Versus Collectivism: A Comparison of Kenyan and American Self-Concepts. Basic and Applied Social Psychology, 19(2):261-273, DOI: 10.1207/s15324834basp1902_7

Pew Research Center. 2019. Adults in the Dallas Metro Area: Religious Composition of Adults in the Dallas Metro Area. Washington, D.C.:

PewResearchCenter.com. URL Access:

https://www.pewforum.org/religious-landscape-

study/metro-area/dallasfort-worth-metro-area/

Robben, Antonius C. G. M., and Jeffrey A. Sluka, eds. 2012. Ethnographic Fieldwork: An Anthropological Reader. Second Edition. Sussex, UK: John Wiley \& Sons, Inc.

Santrock, John W. 2018. Lifespan Development. Nineth Edition. New York, NY: McGraw \& Hill Publishers.

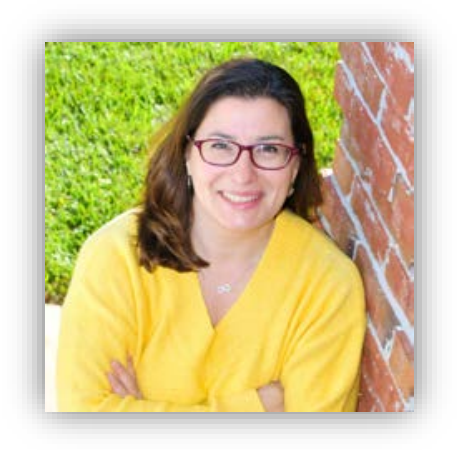

Erin C. Kincaid is a recent graduate of Eastern University's Theological and Cultural Anthropology master's program. Erin is active in her career in social impact and psych-anthropology. She serves as Sr. Director of Education at Brighter Tomorrows, a shelter and crisis care agency for victims of sexual and domestic violence. She is also the founder and lead counselor at Higher Hopes Counseling in her hometown. Erin plans to begin her Ph.D. research in the fall of 2020 with a focus on issues surrounding dignity and violence prevention. Erin is the proud mother of a teen-age son and wife to Will. They live happily, though trying to change the world for the better, in North Texas.

Author email: AnthroErin@gmail.com 